\title{
Marketing their Circuses through Personalization: Class and the Reiterative Celebrity Images of John Ringling and Bertram Mills
}

\begin{abstract}
:
Marketing strategies today often rely on creating an emotional connection to the brand through personalising or humanising the business. This article explores how the American Ringling Bros and Barnum and Bailey and British Bertram Mills Circus both used this strategy in the early twentieth century to encourage audiences to attend their circus over any other. John Ringling and Bertram Mills may best be remembered for totemic images but their celebrity was constructed through a reiterative performance process. I examine the shifts in their representation performed in press, publicity and through anecdote to explore how each iteration of their public identity functioned to publicize their respective circuses at significant points in their fortunes. I also explore how these circus celebrity identities, focused on achieving financial success for a commercial enterprise, activated and perpetuated national self-identities linked to class.
\end{abstract}

Keywords: circus, celebrity, marketing, class, Ringling, Bertram Mills.

Biographical information:

Dr Kate Holmes has recently completed a PhD in Drama at the University of Exeter entitled 'Aerial stars: Femininity, Celebrity and Glamour in the Representations of Female Aerialists in the UK and USA in the 1920s and Early 1930s'. This research explores the celebrity of aerial stars of this period using approaches that range from examining spatial performance practices to female physical culture. Her research has been published in Early Popular Visual Culture and is forthcoming in Stage Women, a collection of essays on early twentieth century female performers edited by Maggie Gale and Kate Dorney. This article examining publicity and celebrity draws upon her previous experience as a qualified marketer.

Contact details: cjh233@exeter.ac.uk/holmeskatej@gmail.com 


\section{Marketing their Circuses through Personalization: Class and the Reiterative Celebrity Images of John Ringling and Bertram Mills}

Circus fans and historians remember John Ringling and Bertram Mills by two images: a cigar and a cornflower boutonniere. In 1932 Earl Chapin May sketched the enduring image of Ringling Bros and Barnum \& Bailey owner, John Ringling, when he said 'you can spot him by his cigar which he smokes or chews incessantly and by a nervous blinking that has been part of John for many years'. 'This visual image of John Ringling always smoking a cigar, whilst perhaps loitering by the circus tent flap, is frequently alluded to by circus fans and historians. ${ }^{2}$ Across the Atlantic, only five years later, a caricature in The Sketch of Bertram Mills proclaims his totem: 'Say It With Cornflowers! King of the circus and coaching enthusiast Bertram W. Mills, J.P., always wears a cornflower in his button-hole'. ${ }^{3}$ The backdrop to Mills' portrait is a crowd of colourful clowns, one of whom reaches across Mills' chest to carefully adjust his bright blue boutonniere. If John Ringling was known by his incessant cigar-smoking, Bertram Wagstaff Mills was even more closely associated with a cornflower deliberately positioned in his button-hole.

These static images are revealing, but they are also a little misleading. What they demonstrate is a commercial strategy of personalization that is still a core principle of marketing today, that is designed to improve brand recognition and loyalty by creating a personal emotional connection with consumers. ${ }^{4}$ Both men performed themselves as circus celebrity impresarios by conflating their public identities with their businesses to gain economic success; constructing themselves as notable public figures through press and publicity. This is a very specific type of celebrity: one that is less about the allure experienced by audiences and all about constructing an image that secures financial gain. But, in focusing too heavily on the static images of the man holding the cigar and the man wearing the cornflower, what lies behind the shifting representations of John Ringling and Bertram Mills is obscured. The key to understanding their celebrity images, is as a reframing of Judith Butler's notion of performance as a process. Instead of being concerned with gender, the 'reiterative power of discourse to produce the phenomena that it regulates and constrains ${ }^{5}$ is instead concerned with commerce; and as such constructing a commercial public identity is reiteratively developed via a series of 
celebrity images. In each reiterative representation, personalizing the circus brand may be the central marketing strategy, but it is how personalization is activated at significant points in the history of these circuses that has the potential to disclose more. This concern with commercial success means that the discourse produced by the representations of these circus impresarios surrounded the social structures that support capitalism, perpetuating national self-identities linked to class.

I am not the first to suggest circus publicity has the power to reveal national selfidentities surrounding social structures but I am the first to consider it a reiterative performance process. Of Phillip Astley, the man credited with establishing modern circus, Marius Kwint states: 'The history of circus has been bound up with a classinflected history of national identity'. ${ }^{6}$ Whilst Yoram Carmeli has identified a 'bourgeois hegemony' in British popular circus literature from the early twentieth century, through its preoccupations with lineage, royal attendance and the British roots of modern circus. Although Carmeli considers class a specifically British one, this concern with genealogy is not unique to British circus. Lineage persistently reoccurs throughout 1920s and 1930s American press and publicity surrounding performers who followed their family into the circus. Social hierarchies are central to how circus describes itself, and in John Ringling and Bertram Mills are two pervasive images: the American Dream and the connected English gentleman. Yet, what appears to divide these two images unites them. Fiona Devine notes that although both the USA and UK have remarkably similar social structures that popular images, such as the two described here, overstate the differences between both nations. Both are hierarchical societies whose economic histories developed in similar ways, but each nation has a very different self-identity around the notion of class and of how it is used to rationalize social inequalities. ${ }^{8}$ It is because the public representations John Ringling and Bertram Mills presented were aimed at commercial success that they reflect such enduring class-based images of national selfidentity.

Considering John Ringling and Bertram Mills' public identities as reiterative has led me to select moments where their representations were established or shifted. I begin by considering how John Ringling and his brothers personalized their brand as a family. Later, the deaths of his siblings forced an iteration of John as sole owner, and yet another, when his purchase of the American Circus Corporation threatened the 
American Dream as he nearly lost the family circus. Bertram Mills borrowed more than just the strategy of personalisation from John Ringling when he set up his circus.

Anecdote links both men and demonstrates how Bertram Mills first represented himself simultaneously as a connected British gentleman and an underdog able to succeed against the odds. Later iterations of his identity shifted to emphasize his links to the aristocracy with the aim of appealing to the British obsession with elite society as celebrity. Probing these men's representations at these significant moments via a diverse range of archival sources and anecdote, enables me to question the historiographies that surround these circus men and compare what lies behind national tropes of what makes a successful businessman.

\section{American Celebrity Circus Monarchs: John Ringling and His Brothers}

Before John Ringling became so closely associated with his cigar, his celebrity identity was as one of five brothers. Al, Otto, Alf, Charles and John Ringling dominate histories of the American circus from the late nineteenth to the early twentieth century with a story that is represented as definitively American. It is a rags-to-riches American Dream where the children of a German immigrant harness maker, August Rüngeling, established a circus that became the largest and most important in the world. ${ }^{9}$ Davis notes that this story was created by the brothers themselves through a range of posters such as Figure 1 and through the 1900 Life Story of the Ringling Brothers written by Alf T Ringling. For Davis, the deliberate objective of this narrative structure was to 'validate the high moral character of the circus'. ${ }^{10}$ Although, publicity material reveals this emphasis, it also demonstrates a strategy of personalization, where the American Dream reflects how America liked, and likes, to see itself as a classless society. 
Picture removed for copyright reasons

Figure 1: 'Ringling Bros' Monarchs of the Circus World', 1901 poster, printed by the Courier Company, Buffalo, from the Fred D. Pfening III collection in the Jerome Lawrence \& Robert E. Lee Theatre Research Institute of the Ohio State University Libraries.

Readjusting the emphasis of the American Dream narrative from validating circus to one of humanising big business, reveals Figure 1 as connecting this huge circus with the Ringling brothers as a family. Their circus may risk being impersonal due to its size, but it is a family enterprize run by people you can recognize. Looking at this poster, it is the brothers who immediately draw the eye and who stress their familial relationship through common dress and facial hair. Their image grabs attention through the bright yellow train of elephants that encircles it and because their picture is the largest within the composition. Yellow is the brightest colour on the poster and links the brothers' depiction directly to the title strip at the top of the image; these are the Ringlings and this is their circus. From these two points my eye takes in the other elements of the poster in a circular fashion, moving to the rest of the right section before travelling left.

Surrounding the brothers is their current success, confirmed by the large herd of elephants shown in the programme that year, by the considerable logistics required to transport their show, the international nature of exhibits, and the title the 'World's Greatest Show'. The location of the Ringlings and these attractions within the same section of the poster, provides a set of reasons to see this Ringling circus, this year. My eye finally comes to rest on the representations of their early trials and difficulties. Through grit and 
determination, the men on the left worked hard to become the successful men on the right; 'the Monarchs of the Circus World' who are at the top of the circus power structure. Other circus impresarios included their image on posters, but this Ringling poster connects their success, their American Dream, to a frequently retold story of their lives. One that deliberately connects the brothers' identities to their circus with the aim of creating an emotional bond between the American consumer and an enterprize that had the potential to be impersonal due to its vast scale.

Publicity did not just aim to provide a direct and personal connection to the brothers as a family unit. It sought a deeper level of identification, where each brother's contribution could be imagined. The autobiography Life Story of the Ringling Brothers provided readers with the opportunity to imagine individuals who each had their special role to play in running the circus. Published in 1900 by Alf T Ringling, it presents Alf T as managing the press department, Charles advertising, John transportation and routing, Otto finances and $\mathrm{Al}$ the smooth running of performances as Equestrian Director. Of course, Alf is also careful to stress how they all shared the authority of the circus without the need to legally ensure filial compliance through contracts. ${ }^{11}$ Once the reader had reached the final pages of Life Story of the Ringling Bros they had been invited to imagine the trials and hardships the brothers had overcome as a close family unit, some of which appear in Figure 1 a year later. But, more importantly, they could also imagine each brother's role in the huge circus that bore their name, reflecting the trope of circus as family or temporary community. The Ringling Bros World's Greatest Show would not be an anonymous behemoth travelling the country, but instead could be imagined by audiences as a family show run by brothers with individual responsibilities. Providing this carefully presented glimpse into their lives allowed audiences to imagine they knew the men behind one of America's largest circuses.

Sitting on benches waiting for the circus to begin, audience members could consult programmes and feel a connection to the brothers through these same tactics: through reading the family story and absorbing visual imagery that sold the brothers' involvement as a reason to see a Ringling circus over any other. The earliest programme I have found the story of the brothers retold in was the 1905/6 The Field of the Cloth of Gold spectacle programme. ${ }^{12}$ Here, their triumphs over adversity and hard won road to success are spread over five pages, each illustrated by a photograph of one of the brothers. As 
audience members leafed through the programme and engaged with the narrative, they gazed upon images of each brother, distributing specific roles to each sibling. A few years later, the most dominant image on the 1909 cover of the Ringling programme ${ }^{13}$ was that of the five brothers, that comprises the central third of the page. As in the poster above, the brothers are surrounded by attractions: clowns, acrobats, an aerialist, a hippopotamus and a lion. The reliance of the composition on the Ringling brothers' image reinforces the message that the most important reason to see this circus - or the Unique Selling Point, to use modern marketing language - is the Ringling's management. The process of performing the Ringling celebrity identity for commercial success, was one that relied on repetition, reinforcing previous messages. However, it was also one that capitalised on this reiterative process. By the late 1920s, this story had achieved enough familiarity to be deemed 'too well known to be repeated' in full, but was still referred to in a truncated form in every souvenir programme. ${ }^{14}$ The fact it still featured in programmes demonstrates how successfully the brothers had conflated their personal story with their circus and how important the Ringling family identity was to its success.

The publicity described above personalized the Ringling brand by using the brothers' image and carefully presented a story that activated a powerful myth of American selfidentity. If five brothers could create one of America's largest circuses from nothing, then they were just like any other American watching from the stands, and any American could apply themselves and achieve what they had. The American Dream is at the heart of American self-identity and 'promise[s] that all Americans have a reasonable chance to achieve success as they define it - material or otherwise - through their own efforts, and to attain virtue and fulfilment through success' ${ }^{15}$ By using this narrative form the Ringlings were activating the myth that America is the classless 'land of opportunity' where anyone can succeed and move to the top of society through the power of work. However, they also reinstated those hierarchies by terming themselves 'Monarchs' of the circus, such as in Figure 1. This rags-to-riches narrative shows Ringling publicity, and therefore circus, as reflecting the gap between American cultural self-identity and the social reality of living in America's hierarchical society.

\section{John Ringling: Circus King \& Figurehead}

By the 1920s, the tactics employed by the Ringling family had successfully conflated the identities of the two remaining brothers, John and Charles, with the Ringling circus. This was partly enforced by the deaths of the other partner-brothers from 1911 onwards, ${ }^{16}$ 
but also from changes in the business structure. In the years that followed John Ringling's public image took on different iterations as he attempted to recreate himself as an entrepreneur with more diverse business interests. Ultimately, the most profound shift in his public identity resulted from the disastrous American Circus Corporation purchase in 1929. It is following this acquisition that John Ringling became a figurehead, losing control of the circus he and his brothers had built from nothing. Two descriptions of John Ringling exist depending on the date the history was written; two iterations that diverge in characterising John as self-effacing or arrogant.

At the beginning of the 1920s, John Ringling's public role in the circus was as the brother who sourced talent from throughout Europe and North America and to whom performers felt accountable. ${ }^{17}$ In 1919 John and Charles merged the two units they owned, Ringling Bros and Barnum and Bailey, into one combined unit. Following this merger, they began to rely on experienced managers such as Pat Valdo and Fred Bradna to perform some of the activities previously attributed to the dead brothers. ${ }^{18}$ For Tiny Kline, 'Mr John' was 'our boss', the man whose approval she sought and who booked her act. ${ }^{19}$ It was also John who signed the aerialist Luisita Leers for the 1928 season in Havana, Cuba. ${ }^{20}$ By the 1920s, John Ringling's appearance at a non-Ringling circus signified he was scouting for performers.

He may have derived his success from the family circus, but John Ringling wanted to be known in the public imagination as more than just a celebrity circus impresario. David C Weeks describes John Ringling's diverse investments in the railroad, art and developments in his adopted home of Sarasota, Florida as an attempt to prevent himself from being connected solely with the circus. Rather than distancing his identity from his core business, this resulted in his being known primarily as the circus man, but also as an entrepreneur. It may be tempting to underplay John Ringling's celebrity, but Weeks highlights that his divorce from his second wife Emily, 'was treated as a celebrity case and reported in the national press'. ${ }^{21}$ Regardless of any attempts to escape his showman image in his later years, the circus had been wedded so successfully to John's image in the early 1900 s that by the 1920 s, this was the primary characteristic of his celebrity.

Later representations of John Ringling hinge on when they were written and whether it was public knowledge that he had lost control of the family circus, remaining as no more 
than a figurehead by 1932. Histories written once the events were public knowledge embed John Ringling's arrogance into a story that hangs on disputes over Madison Square Garden and Friday night boxing. One of the more fictionalized accounts reveals the extent to which this character attribute drives the story: 'The tenant roared: 'Me call off the circus for a couple of lousy boxers fighting up there? I helped build this garden!' ${ }^{22}$ Even Weeks, who presents a more balanced opinion of John Ringling than appears elsewhere, considers Charles Ringling to have had a moderating influence on his brother. ${ }^{23}$ In these later histories it is John Ringling's arrogance following Charles' death in 1926 that is responsible for his decision to purchase the American Circus Corporation. It is arrogance that led him to make the decision without consulting any of his business associates, including Charles' wife Edith, who is later considered to have become one of his bitterest adversaries. ${ }^{24}$ It is John Ringling's pride and egotism that is represented as responsible for the American Dream faltering and the circus built from nothing by his family, being lost.

Although John Ringling made some questionable decisions, he was also unlucky. Madison Square Garden was an important venue for the Ringling-Barnum circus. Most of the season was spent travelling the USA on the railroad, but New York provided the 'the largest market in the country', with audiences of over one million people. ${ }^{25}$ Madison Square Garden had become closely associated with the Ringling circus and John Ringling had a personal connection to the venue. He had been the Vice-President of the investment consortium that built and managed the new venue in $1925 .{ }^{26}$ But, in 1929 John Ringling was no longer a major shareholder ${ }^{27}$ whilst his friend and the Gardens' manager, George Lewis 'Tex' Rickard had died earlier that year. ${ }^{28}$ The new management, headed by William Carey, sought to renegotiate the terms of the circus contract, claiming that the financial loss to the Gardens of Friday night boxing matches during the circus season would cost the arena too much money. ${ }^{29}$ The new management approved a fresh contract that required the Ringling-Barnum circus to forgo Friday night performances at a time when John Ringling was sourcing talent in Europe. ${ }^{30}$ The disagreement resulted in Madison Square Garden offering the circus season to Ringling's largest competitor, the American Circus Corporation, who planned to open both their Sells-Floto and HagenbeckWallace circuses from the venue in a combined show. John Ringling sought to retain the dates by purchasing the American Circus Corporation. Unfortunately, he financed the $\$ 2,000,000$ purchase price using a loan for $\$ 1,700,000$ weeks before the Wall Street 
Crash. ${ }^{31}$ As a leisure industry, circus could not avoid the effects of the Great Depression and attendance figures fell. ${ }^{32}$ Despite employing strategies to adjust to the new economic situation John Ringling defaulted on the loan and the New York Investors became his creditors. ${ }^{33}$ By 1938, less than ten years after the Wall Street Crash and John Ringling's purchase, none of the American Circus Corporation circuses had survived the effects of the Depression. ${ }^{34}$ The title not permitted to fail, was Ringling Bros and Barnum \& Bailey. The New York Investors installed Samuel Gumpertz as General Manager from 1932 to 1937 because of his close financial ties to the creditors through real estate dealings and his background as an acrobat, Wild West rider and Coney Island manager. ${ }^{35}$ Publicly they stated this change in management was due to John Ringling's genuine ill health, ${ }^{36}$ whilst he remained president of the circus purely 'for the sake of his name'. ${ }^{37}$

The good name of John Ringling was very important to the success of the Ringling circus in this difficult financial situation. The iteration of Ringling presented at the time was the polar opposite to the one recounted in histories since. Writing in 1932, Earl Chapin May describes John as having the character trait of 'self-effacement ${ }^{38}$ rather than arrogance. Had the American Circus Corporation purchase been successful he might still be remembered as May described him. But, in losing the circus that he and his brothers had built from a small wagon show into the world's largest circus, John Ringling represented the American Dream gone wrong - as a result, he cannot be remembered with virtue. ${ }^{39}$ At the time, that was precisely how he needed to appear to weather the risky financial situation. The strategy of personalization had so strongly associated John Ringling with the Ringling-Barnum circus that breaking that connection risked negative publicity. 1933 was the Golden Jubilee season and an opportunity to exploit the Ringling family name. Representing John Ringling as arrogant could only have distanced consumers from the circus because arrogance implies not needing the help of others, of thinking oneself as more important. Now, more than at any other time, the public identity of John Ringling needed to appear identifiable and approachable; that emotional connection established over many years, was needed to make his circus the one you bought a ticket to this year.

\section{Transatlantic Connections}

John Ringling and Bertram Wagstaff Mills are linked in circus history through the genesis story of Bertram Mills Circus. This story and the publicity it produced demonstrate Mills using the strategy of personalization, one which he likely borrowed from John Ringling. 
But, it also positions the Bertram Mills Circus on a par with the world-renowned Ringling Bros and Barnum \& Bailey Combined Show and its impresarios as comparable. The anecdote begins with Mills visiting the Wilkins and Young Circus at Olympia as a guest of the venue's management in 1919 and sets the tenor of Mills' circus identity as a connected English gentlemen from the very start. Over a post-show dinner he was asked his opinion of the circus and responded 'If I couldn't do better I'd eat my hat'. ${ }^{40}$ The story then varies as to whether Mills was asked by Reginald Heaton, the Managing Director of Olympia to stage the next year's show because he was thought to have the ability, or, if he was bet $£ 100$ pounds by Lord Daresbury to do so. ${ }^{41}$ Both versions of the story position Mills as connected to important social and industrial figures and, it is via these connections that he is said to have secured a contract to bring the Ringling circus to Olympia. This was obtained either because Mills met John Ringling at the New York International Horse Fair, or John McEntee Boorman was in London and willing to approach his friend, John Ringling, on Mills' behalf. ${ }^{42}$ However, the contract required that Ringling arrange the shipping of his circus to London. This condition was stipulated because Britain's shipping industry had been severely damaged by the First World War, but Ringling was unable to find the sufficient shipping space and cancelled the contract in June, offering Mills compensation. Bertram Mills turned down this offer and decided to produce his own European style single-ring circus. He began travelling Europe with his son, Cyril Mills, to source his programme. ${ }^{43}$

Considering the recent consolidation of Ringling operations from two units into one, it is unlikely that a Ringling circus at Olympia was ever a reality and that the anecdote was purely a means of generating publicity. As popular circus historian, David Jamieson, observes: it seems unlikely that Ringling would contemplate bringing his entire circus across the Atlantic for just five weeks, as the revenue could hardly justify the travel costs, unless a tour of European exhibition halls or under canvas was being considered' ${ }^{44}$ After all, 1920 was only a year after the merger of the separate Ringling and Barnum units into the giant Ringling-Barnum show. The Ringling business model at this time was for consolidation $^{45}$ and not diversification into other markets, particularly those that were still recovering from the Great War. The more likely answer is that John Ringling agreed to assist Bertram Mills by permitting him to print the story, particularly as the British market was of no interest to Ringling. ${ }^{46}$ John Ringling may also have suggested hiring two of his key managers: Clyde Ingalls (the announcer who also worked as Fun Fair 
Manager at Bertram Mills Circus) and Merle Evans (Bandmaster). Both appeared in Bertram Mills during the first two seasons at Olympia, with Ingalls maintaining his relationship by returning for various seasons throughout the 1920s. ${ }^{47}$ Analysis of this anecdote reveals a business relationship existed between Mills and Ringling - just not the one presented to the public.

The story is carefully judged to cast favourable light on both Bertram Mills and John Ringling. John Ringling is only prevented from bringing his circus to England by global transport issues outside his control, whilst he graciously offers to compensate Mills. This iteration of John Ringling as generous is in line with May's characterisation of Ringling as more virtuous than histories written after 1932 suggest. Through this story Ringling's public identity is given a boost, but Mills gains the most. He is depicted as a British underdog triumphing against the odds because he pulls together a high-quality circus of international renown at short notice.

In describing how Mills and his son scouted for talent there is a similarity in Bertram Mills and John Ringling's representations. Both circus impresarios are portrayed as travelling the world to personally select only the very best acts for their particular circus. Each circus is tied closely to the impresario's celebrity identity through the programme they present; a programme which is an expression of their own personal tastes and high quality standards. The extent to which this was an important part of Mills' celebrity image is seen through 'the Quality Show' tagline the Bertram Mills Circus gave itself, and through Cyril Mills' later iteration of the myth, when he let it be known that he flew himself on his scouting trips in his personal plane. ${ }^{48}$ If an artist stated they were a Ringling or Mills' performer then their act also had the power to reflect negatively or positively on the circus brand and celebrity owner.

The anecdote of Bertram Mills' first season demonstrates Mills' looking to America to succeed, but also highlights a slight difference between the two impresarios. The anecdote suggests that Bertram Mills deliberately emulated the strategy of personalizing the circus brand to achieve success, but this strategy was one that required a national adaptation: in America, the Ringlings evoked the mythical American Dream; whereas in Britain, Bertram Mills astutely framed his public identity as a connected English gentlemen who succeeds due to his position within the British establishment. Mills is not 
a paying patron but a guest of Olympia and is personally asked to establish his circus by the management of the venue. It is his position in society as an affluent and internationally mobile Englishman that provides him with the connections to approach John Ringling and to create his own similarly successful circus at short notice. The trope of triumphing against the adversity is shared by both the American Dream and the British underdog. However, this representation of Bertram Mills demonstrates the British emphasis on using social cachet and business skills to triumph against unforeseen forces outside anyone's control.

\section{The British Celebrity Circus: Bertram Mills \& Elite Society}

Returning to The Sketch caricature of Bertram Mills with his trademark cornflower and John Ringling's depiction in Figure 1, both are represented as at the top of a circus hierarchy: Ringling is a 'monarch' and Mills a 'king'. Ringling's activation of the American Dream has social structures at its heart, but Mills' public identity more explicitly reflected class in wider society because he cultivated a persona that in every iteration represented him as part of the establishment. In fact, Bertram Mills built his success through press and publicity that specifically used social and political elites using two different interlocking strategies: the first involved personalizing his brand as a described above, as a connected English gentleman; and, the second cemented this connection to affluent social and political elites, who were reported on as celebrities, through a ceremonial society lunch held to open the circus. This second strategy did more than just attract customers capable of paying higher ticket prices, it also gained Mills' circus publicity in photojournalistic magazines such as The Sketch by showing the elite social world patronising his show. In class-conscious Britain, this marketing technique gained press coverage where class and celebrity were still connected.

Bertram Mills' identity as a connected English gentleman was developed via more than just the anecdote about how and why he set up his circus. Prior to its establishment, Mills derived his livelihood from horses through the family funeral and coach business. This is presented as a reason for his interest in the circus, which relied heavily on equestrianism in its programmes and because the Continental horse show often occurred at the same time as the circus. According to his son, Cyril Mills, it was his 'great love of horses $^{\text {'49 }}$ that led Bertram Mills to develop close friendships with two directors of Olympia which was also the location of the International Horse Show. However, Jamieson observes that this choice to diversify, was probably a need to develop new 
business interests, as the coach building industry was under threat from the motorcar. It is telling that in describing this business situation that Jamieson uses Mills' rank, describing him as 'Captain' and mentioning his unit, the Royal Army Medical Corps. ${ }^{50}$ The persona Mills cultivated to market his circus in his first year drew upon his identity as a horseman and his role in the army to present Mills as a respected English gentleman. ${ }^{51}$

Surveying publicity throughout the 1920s the reiterative performance of Mills' celebrity image is clearly visible. Press coverage and programme notes show a rewriting of why to see this circus, this year that is linked directly to Mills' identity. Images within the first season programme show Mills driving a coach, whilst in The Daily Graphic, Mills appears dressed in riding attire with the title of 'His Own Horse Show. ${ }^{52}$ Mills' public persona is that of an English gentleman performing the gentlemanly pursuit of expert horsemanship. Modern circus developed from equestrianism, permitting Mills' management to appear as a natural extension of his English gentleman persona and his coachbuilding background. Yet, how Mills framed his circus in the first year is different to the second: initially, it was: 'The Great International Circus' 'Organised by Bertram W Mills ${ }^{53}$ but by the second season it had become just 'Bertram W Mills' Olympia Circus'. ${ }^{54}$ Once Mills' identity was cemented in the public imagination with the circus, there was no longer a need to market it on its international attractions, it was enough that it was Mills' circus. 
Picture removed for copyright reasons

Figure 2: Bertram Mills Circus Programme (1924-5), private collection

This reiterative process of marketing his circus through his personal identity was one that aligned Mills' persona closer and closer to affluent elite society. From 1922 Mills' friend, the Earl of Lonsdale, became Honorary President of the Circus ${ }^{55}$ and by the 1924-5 season a regular page presenting both of their photographs together was included within the Bertram Mills programme (Figure 2). This image juxtaposed Mills in formal dress, wearing his cornflower, alongside the Earl of Lonsdale. This first appearance of Lonsdale's image in a Bertram Mills programme presented their photographs against a background including illustrations full of horse-riding references such as saddles and horseshoes. Although the Earl of Lonsdale appears above Mills, it is Mills' photograph that draws the eye. Both men are positioned facing slightly in towards each other as if to signify partnership, but Mills' image suggests ownership through his more formal dress and direct gaze towards the viewer. This composition simultaneously aligns Mills with aristocracy whilst drawing upon his public persona as an expert horseman and English gentlemen.

Mills' decision to connect his identity with the elite social world extended beyond cultivating this public persona in press and programmes. Instead he successfully sought to position his circus as part of elite society's social calendar by establishing opening 'luncheons' from 1922. The lunch itself was a ceremonial event that took advantage of 
the spectacle afforded by a visit from the Lord Mayor and Sheriffs of London to create publicity. First, the press photographers arrived. Then, the Earl of Lonsdale, received the guests of honour as the luncheon's official host, before, the 'City pageant' that included the processing of the Lord Mayor's mace..$^{56}$ In some years a cocktail reception would precede the lunch which would itself be concluded by speeches announced by a toastmaster and the official opening of the circus. ${ }^{57}$ Beautifully printed special invitations, souvenir brochures and a complimentary box containing a cigar, cigarettes and matches were designed to cater for elites. ${ }^{58}$ According to Cyril Mills this lunch was designed to encourage journalists to review the show and attract the wealthy because this costly circus needed to attract 'people who could afford the expensive seats'. ${ }^{59}$

Using the Earl of Lonsdale to host these luncheons, rather than Mills, demonstrated Mills' social status; it presented Mills as having enough social cachet that a member of the aristocracy would publicly endorse his show by hosting this public ceremonial event. According to popular circus historian Peter Verney, the lunch became 'one of the most sought-after events of the social calendar', and 'an annual function of considerable importance' according to Cyril Mills. ${ }^{60}$ It is tempting to consider this an over-statement but by 1928 the lunch was described as a 'State Visit' on invitations and souvenir materials, and by 1933 the dignitaries listed on the table plan included both Prince George and Ramsay MacDonald, the then Prime Minister. ${ }^{61}$ Throughout the 1920s and 1930s the lunch and the circus it popularized, became fashionable amongst the visible social and political elites of London society. In 1927350 guests attended the lunch but by 1936 the event attracted a record 1,493 guests. ${ }^{62}$ By the early-1930s the opening lunches had become a significant date within the London social calendar.

David Cannadine has identified the early twentieth century as a time when such public ceremonial ritualized events proliferated. These events visibly 'display[ed] community-ashierarchy' at a time when 'the traditional ordering of society seemed under unprecedented attack'. ${ }^{33}$ The ceremonial circus opening was one of a number of public rituals that visibly emphasized the hierarchies in interwar British society when these were being questioned. But, it also provided access to 'four hundred critics... represent[ing] every daily and weekly magazine in the country'. ${ }^{64}$ This ceremonial lunch was both an effective marketing tool and a ritual that reflected the apparent instability of class in British society. 
Coverage of the circus opening was not just restricted to the ceremonial lunch but also to the show itself. One double-page article in The Sketch presents photographs of the audience on the left and acts on the facing page, under the title "Wish Fulfilment at Olympia - Circus Wonders and Notabilities Who Saw Them'. ${ }^{65}$ All the 'notabilities' but one presented across five images, carry an aristocratic title, whilst on the right are: dog, perch (a long pole), unicycle and knife thrower acts. This coverage devotes as much space to who is attending the circus as to who is performing in it. The premiere of Bertram Mills Circus was part of a celebrity culture that focused on the frequently photographed activities of elites. The ceremonial lunch and the circus opening are an example of Bertram Mills using his position within the establishment to raise the profile of his circus.

From the late 1920s Bertram Mills began publishing articles that simultaneously linked his identity to his circus, but that also presented an iteration of his image that positioned him as a circus expert. Their placement focused on providing a personal and direct link between Bertram Mills and his circus within the minds of readers, at the same time as educating readers about the circus more generally. This began with articles such as 'Children of the Sawdust Ring' and 'Women of the Circus', and later developed into a series of full-page articles first entitled 'Secrets of Circus Life' printed in the News of the World in 1934 ${ }^{66}$ This News of the World series was popular enough to be recommissioned during the 1935-6 and 1936-7 seasons. ${ }^{67}$ Printed on the same page every week they included a photograph of Mills or one of his sons, alongside anecdotes, stories and insights into running an international circus.

By the mid 1930s, Bertram Mills had successfully personalized the Bertram Mills Circus brand by aligning his public image with that of the circus that bore his name. He cultivated a public identity that drew on his background as a horseman to present himself first as an English gentleman, then as a friend of the aristocracy. Further reiterations of his identity used this connection with elite society to embed his circus into London's social calendar, attracting affluent audiences and gaining valuable coverage in photojournalistic magazines and newspapers preoccupied with interwar society-celebrity. By bringing press and aristocracy together Mills positioned his circus as part of British celebrity culture. Mills has been credited with inspiring a renaissance of British circus 
following the First World War, but his brilliance as a businessman and marketer has never properly been analyzed. He galvanized a British interest in society-celebrity in personalizing and publicising Bertram Mills' circus, and in doing so, attracted diverse audiences to his circus.

\section{Reiterative Celebrity \& Hierarchies}

Exploring how John Ringing and Bertram Mills personalized their circuses demonstrates that early twentieth-century circuses employed sophisticated marketing strategies that relied on repetition. Once a message had become a public association, it could be adapted for commercial success, creating another iteration of an identity. Recognising that this process of personalization constructed circus impresarios as celebrities reveals circus celebrity culture as stratified and interconnected. Circus celebrities comprised not just performers but also the men who ran the most globally important circuses. By appearing in Ringling Bros and Barnum \& Bailey or Bertram Mills circuses, a performer gained status and prestige for an act, but also reflected on the quality of the circus and the standards of its impresario.

Understanding the commercial nature of John Ringling and Bertram Mills' constructed identities as revealing national self-identities around class exposes the unlikely similarities in their depictions. Both men are presented as triumphing against the odds as an example of the American Dream or as the British underdog. In America, this narrative evoked an ideology of American classlessness that was so central to the Ringling identity that it could not be publicly challenged by John Ringling's disastrous final acquisition. However, in also framing themselves as Monarchs, the Ringlings simultaneously reflected the desire for a classless society and expressed the inequalities present within American society. For Bertram Mills, this representation was only useful in securing success for his first year, and instead his central representation was as a part of the establishment. This depiction and Mills' use of a ceremonial ritualized event, the opening circus lunch, expressed an interwar concern about the instability of social structures in Britain. In 1920s and 1930s America and Britain, the reiterations that constructed the celebrity identities of John Ringling and Bertram Mills were successful marketing strategies because they expressed similar national tensions about social mobility. Understanding their celebrity as dynamically reiterative, rather than static, permits each circus man to reveal more about national tropes of success and self-identities of class. 


\section{References \& Notes:}

${ }^{1}$ Earl Chapin May, The Circus from Rome to Ringling (New York: Dover Publications Inc, 1963), p. 329.

2 Tiny Kline, Circus Queen \& Tinker Bell - the Memoir of Tiny Kline, Janet M. Davis, ed. (Urbano \& Chicago: University of Illinois Press, 2008) p.197; David C. Weeks, Ringling: The Florida Years, 1911-1936 (Gainesville: University Press of Florida, 1993) p. 83.

3 'Say It With Cornflowers!' The Sketch, (22 December 1937) p. 565, Mander \& Mitchenson Collection (TC/MM/REF/TH/SU/CI/29), University of Bristol Theatre Collection.

${ }^{4}$ John Ringling and Bertram Mills were working across a significant era in the development of marketing practices. See: Ronald A Fullerton, 'How Modern is Modern Marketing? Marketing's Evolution and the Myth of the "Production Era", Journal of Marketing, 52, January (1988), pp 108-125, where Fullerton disproves Robert J Keith's influential and enduring 'Production', 'Sales' and 'Marketing' era periodisation. Instead he designates the mid-nineteenth century to 1929 as 'The Era of Institutional Development' when 'many of the practices of modern marketing first appeared' (p. 122).

${ }^{5}$ Judith Butler, Bodies that Matter: On the Discursive Limits of "Sex" (New York, Routledge, 1993) p. 2.

${ }^{6}$ Marius Kwint, 2012. 'Circus', in David Wiles \& Christine Dymkowski, eds., The Cambridge Companion to Theatre History (Cambridge: Cambridge University Press, 2012) p.221.

7 Yoram S. Carmeli, 'The invention of circus and bourgeois hegemony: A glance at British circus books', Journal of Popular Culture, 29, No. 1 (1995) pp.213-221.

${ }^{8}$ Fiona Devine, Social Class in America and Britain (Edinburgh: Edinburgh University Press, 1997) pp. x \& 12.

${ }^{9}$ Janet M Davis, Circus Age: Culture and Society under the American Big Top (Chapel Hill: North Carolina Press, 2002) p.60.

${ }^{10}$ Janet M Davis, 'The Circus Americanized', in Susan Weber, Kenneth L. Ames, \& Matthew Wittmann, eds, The American Circus (New York, New Haven \& London: Bard Graduate Center \& Yale University Press, 2012) p. 41.

11 Alf T Ringling, Life Story of the Ringling Brothers (Chicago: RR Donnelley \& Sons Company, 1900) pp. 23842.

12 Ringling Bros, The Field of the Cloth of Gold Spec Souvenir Programme (1905/6), HTC MS Thr 675 (396), George Brinton Beal Collection, Harvard Theatre Collection.

${ }^{13}$ Ringling Bros, Ringling Bros Worlds Greatest Show Magazine of Wonders and Daily Review (1909) HTC MS Thr 675 (398), George Brinton Beal Collection, Harvard Theatre Collection.

${ }^{14}$ See for example: Ringling Bros and Barnum \& Bailey Circus, Ringling Bros and Barnum \& Bailey Combined Shows Magazine and Daily Review (Washington, Baltimore, Wimington, Trenton Jersey City \& Newark), National Fairground Archive (1929).

${ }^{15}$ Jennifer L Hochschild, Facing Up to the American Dream - Race, Class, and the Soul of the Nation (Princeton: Princeton University Press, 1995) p. xi. Chapter 1 of Hochschild's study provides an analysis of the American dream ideology including its foundational tenets and integral flaws.

16 Weeks, p. 14; Henry Ringling North and Arlen Hatch, The Circus Kings - Our Ringling Family Story

(Gainesville: University Press of Florida, 2008) p. 150.

${ }^{17}$ Davis, 2002, pp. 61 \& 254; North and Hatch, pp. 98, 122 \& 134. 
18 Weeks, p. 72.

${ }^{19}$ Kline, pp. $147,236 \& 242$.

${ }^{20}$ Peta Tait, Circus Bodies: Cultural Identity in Aerial Performance, (London: Routledge, 2005), p. 77.

21 Weeks, pp. 167 \& 249.

22 David L. Hammarstrom, Behind the Big Top, (London: Thomas Yoseloff Ltd, 1980) p. 100.

23 Weeks, p. 110.

${ }^{24}$ Weeks, p. 219, 230, $231 \& 236$

${ }^{25}$ Matthew Wittmann, Circus and the City: New York, 1793-2010, (New York, New Haven \& London: Bard Graduate Center \& Yale University Press, 2012), p. 57 \& 77.

${ }^{26}$ Wittmann, p. 78; May, p. 184.

27 Weeks, p. 218.

${ }^{28}$ Joseph Durso, Madison Square Garden - 100 Years of History (New York: Simon and Schuster, 1979) p. 152.

${ }^{29}$ May reports the figure as $\$ 40,000$, p. 184 . I consider Weeks' $\$ 60,000$ as more reliable due to his access to probate and liquidation records, p. 218.

${ }^{30}$ Weeks pp. 218-9.

${ }^{31}$ Weeks, p. 219; Wittmann, pp. 78-9.

32 Davis, 2002, p. 324.

${ }^{33}$ How the loan led John Ringling to lose control of his circus is complicated and is described in detail by Weeks using probate and liquidation records, pp. 257-85.

${ }^{34}$ George L. Chindahl, A History of the Circus in America, (Caldwell: The Caxton Printers Ltd, 1959), pp. 161 3.

35 Davis, 2002, pp. 40-1.

36 Davis, 2002, p. 40; Weeks, pp. $236 \& 238$.

${ }^{37}$ North and Hatch, p. 225.

${ }^{38}$ May, p. 329.

${ }^{39}$ The association of success with virtue is one of the core tenets of the American Dream identified by Hochschild, pp. 23-4.

${ }^{40}$ Cyril Mills, Bertram Mills Circus: its story (London: Hutchinson of London, 1967) p. 15.

${ }^{41}$ Cyril Mills, p. 15; Rupert Croft-Cooke and W.S Meadmore, The Sawdust Ring (Watford: Odhams Press Ltd, 1946) p. 112.

${ }^{42}$ For meeting in person, see: Cyril Mills, p.15 and for contact via Boorman see Rupert Crofte Cooke and Peter Coates, Circus: A World History (London: Elek, 1976) p.112; David Jamieson, Bertram Mills - The Circus That Travelled By Train, A Pictorial Celebration of "The Quality Show" CD., (Buntingford: Aardvark Publishing, 1998) p. 13.

${ }^{43}$ Cyril Mills, p. 16.

${ }^{44}$ Jamieson, p. 13-4.

${ }^{45}$ I argue the Ringling's were employing a business strategy of acquisition and consolidation at this time in: Kate Holmes, Aerial Stars: Femininity, Celebrity \& Glamour in the Representations of Female Aerialists in the UK \& US $A$ in the 1920s and Early 1930s, PhD thesis (University of Exeter, 2016) p. 39-44. 
46 The Ringling brothers monopolized on the absence of Barnum \& Bailey during their 1897 to 1902 tour to dominate the American market (see Davis, 2002, p. 40), making it unlikely John and Charles Ringling would risk embarking on a similar tour focused on the British market.

${ }^{47}$ For both Ingalls \& Evans: Bertram Mills Circus (1920); Bertram Mills (1921). For Ingalls' later involvement examples include: Bertram Mills Circus, Olympia Programme (1924-5), V\&A, GB 71 THM/196/1/3/1, V\&A Theatre and Performance Archives; Bertram Mills Circus, Olympia programme (1925-6), Mander \& Mitchenson Collection MM/REF/TS/CIR/Box 1376, University of Bristol Theatre Collection.

${ }^{48}$ Mills, p. 84; A Stanley Williamson, On the Road with Bertram Mills (London: Chatto \& Windus, 1938) p. 9.

${ }^{49}$ Cyril B. Mills, Bertram Mills Circus: its story (London: Hutchinson of London, 1967) p. 14.

${ }^{50}$ Jamieson, p. 13.

${ }^{51}$ Jamieson, p. 13; 'Round and About Notes', The Tatler (15 December 1920), First Season Press Cuttings, Cyril Mills Collection, V\&A GB 71 THM/196/1/5/6, V\&A Theatre \& Performance Archives.

52 'His Own Horse Show', Daily Graphic (21 December 1920) First Season Press Cuttings V\&A GB 71 THM/196/1/5/6, V\&A Theatre \& Performance Archives.

${ }^{53}$ Cyril Mills, p. 20; Bertram Mills Circus, Olympia Programme (1920-1), V\&A, GB 71 THM/196/1/3/1, V\&A Theatre and Performance Archives.

${ }^{54}$ Bertram Mills Circus. Olympia Souvenir programme, (16 December 1921) V\&A THM/196, V\&A Theatre \& Performance Archives.

${ }^{55}$ Cyril Mills, p. 21.

56 Williamson, p. 225.

${ }^{57}$ Cyril Mills, p. 21; Williamson, pp. 224-6.

${ }^{58}$ Souvenir programmes are in the Cyril Mills Collection, V\&A GB 71 THM/196/1/3 whilst Jamieson describes the box, p. 131.

${ }^{59}$ Cyril Mills, p. 20.

${ }^{60}$ Peter Verney, Here Comes the Circus (London: Paddington Press, 1978) p. 74; Cyril Mills, p. 21.

${ }^{61}$ Bertram Mills Circus, 'Opening Lunch Menu \& Programme’, (20 December 1928), Cyril Mills Collection GB 71 THM/196/1/4/2, V\&A Theatre and Performance Archives; Bertram Mills Circus, '1933-34 Inaugural Luncheon at Olympia Table Plan and Names in Alphabetical Order', (21 December 1933), Cyril Mills Collection GB 71 THM/196/1/4/3, V\&A Theatre and Performance Archives.

${ }^{62}$ Cyril Mills, p. 22.

${ }^{63}$ David Cannadine, Class in Britain (London: Penguin, 2000) pp. 142 \& 143.

${ }^{64}$ Williamson, p. 226.

65 'Wish Fulfilment at Olympia - Circus Wonders and Notabilities Who Saw Them', The Sketch, (2 January 1935) pp. 30-1, Mander \& Mitchenson Collection, MM/REF/TS/CIR/Box 1376, University of Bristol Theatre Collection.

${ }^{66}$ Bertram Wagstaff Mills, 'Children of the Sawdust Ring' (29 December 1929), Mander \& Mitchenson Collection MM/REF/TH/SU/CI/29, University of Bristol Theatre Collection; Bertram W. Mills, 'Women of the Circus', Daily Herald (21 December 1931), Mander \& Mitchenson Collection,

MM/REF/TS/CIR/Box 1376, University of Bristol Theatre Collection.

'Secrets of Circus Life' series include: Bertram W. Mills, 'Secrets of Circus Life, No. 1. Big Moments 
Beneath the "Big Top"”, News of the World (16 December 1934) p. 5; Bertram W. Mills, 'Secrets of Circus Life, No. 3. Round the World for a Circus', News of the World (30 December 1934) p. 5; Bertram W. Mills, 'Secrets of Circus Life, No. 4. Footing the Bill of the Big Top', News of the World (6 January 1935) p. 5. (All articles in the Mander \& Mitchenson Collection MM/REF/TH/SU/CI/30, University of Bristol Theatre Collection).

${ }^{67}$ Bertram W. Mills, 'Beneath "the Big Top”, 1. Olympian Days and Nights', News of the World (15

December 1935) p. 5; Bertram W. Mills, 'Beneath “the Big Top”, 4. Thrills and Laughs on the Road', News of the World (5 January 1936) p. 5; Bertram W. Mills, 'Hello! Here We Are Again, Once More Olympia is the Circus "Big Top", News of the World (6 December 1936) p. 5; Bertram W. Mills, 'Hello! Here We Are Again, "Circusitis" is Contagious, If you Catch the Germ you will Enjoy it!', News of the World (13

December 1936) p. 5; Bertram W. Mills, 'Hello! Here we are Again, Hi Hi! Walk Up, Walk Up! ALL About The Fun of The Fair', News of the World (20 December 1936) p. 5. (All articles in Mander \& Mitchenson Collection MM/REF/TH/SU/CI/30, University of Bristol Theatre Collection). 